\title{
Program Kampanye \#Budayabeberes Terhadap Partisipasi Masyarakat Untuk Membuang Sampah Sendiri
}

\author{
Siti Khadijah', Siti Marfuah Yuliati² \\ 1,2,Fakultas Komunikasi, Sastra dan Bahasa, Universitas Islam “45” Bekasi \\ email: kh4d1j4h@gnail.com
}

Cara Sitasi: Siti K, Siti M Y (2021), Program Kampanye \#Budayabeberes Terhadap Partisipasi Masyarakat Untuk Membuang Sampah Sendiri (2021) 21 (1), 25- 31 Retrieved from https://doi.org/10.31294/jc.v19i2

\begin{abstract}
Currently there are many problems in the environmental sector, such as a lack of public awareness in sorting and disposing of waste. Therefore, one of the companies that is actively conducting campaigns to reduce this problem is KFC Indonesia. KFC spreads its \#budayabeberes campaign message via Instagram. The purpose of this study was to determine the effect of the \#budayabeberes campaign on community participation in disposing of their own waste. This research used descriptive explanative method, with a quantitative approach. The sampling technique used accidental sampling. The data collection techniques used questionnaires and interviews. The analysis technique used linear regression. The results in this study state that the cultural campaign program carried out on Instagram has an influence of $46.1 \%$ and the remaining $53.9 \%$ is influenced by other factors such as interest from participants, gifts from an activity, the existence of benefits from activities, and outside motivation. The \#budayabeberes campaign program has a positive and significant effect on community participation in disposing of their own waste with a coefficient value of 1.391.
\end{abstract}

Keywords: Campaign, Community Participation, \#BudayaBeberes

\section{PENDAHULUAN}

Komunikasi memiliki peran dan fungsi yang sangat penting dalam kehidupan bermasyarakat. Salah satu bentuk kegiatan komunikasi adalah kampanye. Namun, tidak semua kampanye dapat dilaksanakan dengan baik. Kampanye yang baik adalah kampanye yang berhasil mencapai tujuannya. Keberhasilan sebuah kampanye sangat dipengaruhi oleh kemampuan penyelenggara kampanye dalam merancang strategi dengan memanfaatkan berbagai sumber daya yang ada (Venus, 2019).

Saat ini banyak kampanye yang digunakan oleh praktisi public relations untuk mencapai tujuan tertentu. Salah satunya seperti restoran makanan cepat saji asal Amerika Serikat yakni Kentucky Fried Chicken (KFC), yang kini gencar mengampanyekan sebuah program yang bernama budaya beberes.

KFC menyerukan ajakan untuk melakukan budaya beberes melalui berbagai media, salah satunya adalah instagram. Pemilihan media sosial instagram sebagai salah satu media kampanye yang dilakukan oleh KFC Indonesia sejalan dengan segmentasi pasar restoran tersebut.

Melihat tujuan dari kampanye budaya beberes, partisipasi yang dilakukan masyarakat sangatlah penting dalam mensukseskan program kampanye tersebut. Tanpa adanya partisipasi dari target atau masyarakat yang bersangkutan, sebuah tujuan tidak akan bisa tercapai (Anggani, 2014).

Berdasarkan latar belakang di atas maka masalah yang akan diangkat dalam penulisan ini adalah bagaimana pengaruh program kampanye budaya beberes dalam menumbuhkan partisipasi khususnya konsumen KFC yang mengikuti akun instagram @kfcindonesia, untuk lebih peduli terhadap kelestarian lingkungan dengan cara membuang sampah makanan sendiri seusai makan.

Rumusan masalah yang diangkat dalam penelitian ini adalah "Apakah ada pegaruh program kampanye budaya beberes terhadap partisipasi masyarakat untuk membuang sampah sendiri?" dengan tujuan penelitian untuk mengetahui pengaruh program kampanye budaya beberes terhadap partisipasi masyarakat untuk membuang sampah sendiri.

\section{METODOLOGI PENELITIAN}

Penelitian ini menggunakan metode penelitian kuantitatif jenis eksplanatif. Penelitian ini akan melihat seberapa besar pengaruh kampanye budaya beberes (variabel X) terhadap partisipasi masyarakat untuk membuang sampah sendiri (variabel Y).

Populasi dalam penelitian ini followers akun resmi KFC Indonesia yakni @kfcindonesia. Karena followers@kfcindonesia selalu bertambah maka penulis menggunakan populasi pada tanggal 14 Desember 2019 yaitu sejumlah 1.200.000 followers. Dari populasi di atas dapat ditarik sampel menggunakan rumus Solvin yaitu sebanyak 100 responden dengan kesalahan 10\%. Penentuan 
responden menggunakan teknik non-probability sampling, yaitu accidental sampling.

Teknik pengambilan data pada penelitian ini yaitu kuesioner, wawancara sebagai data pendukung, dan dokumentasi. Variabel dalam penelitian ini meliputi Progam Kampanye Budaya Beberes sebagai variabel independen (X) dan Partisipasi Masyarakat sebagai variabel dependen $(\mathrm{Y})$.

Pengujian validitas penelitian ini menggunakan rumus Pearson's Correlation (Product Moment) dan pengujian reliabilitas menggunakan rumus Cronbach Alpha. Teknik analisis data yang digunakan dalam penelitian ini adalah teknik analisis regresi linier sederhana. Hipotesis dalam penelitian ini adalah:

Ha: Terdapat pengaruh program kampanye budaya beberes ter-hadap partisipasi masyarakat untuk membuang sampah sendiri.

Ho: Tidak terdapat pengaruh pro-gram kampanye budaya beberes terhadap partisipasi masyarakat untuk membuang sampah sendiri.

\section{HASIL DAN PEMBAHASAN}

Dalam penelitian ini digunakan 30 butir penyataan dalam kuesioner yang disebarkan secara online, menggunakan bantuan google form dan sudah diisi oleh 100 responden. Karakteristik responden dalam penelitian ini terbagi atas jenis kelamin, usia, pendidikan, pekerjaan, pendapatan, dan wilayah tempat tinggal.

\section{Jenis Kelamin}

Pada penelitian ini, responden lebih banyak wanita dari pada pria. Karakteristik jenis kelamin responden akan dijelaskan pada grafik sebagai berikut:

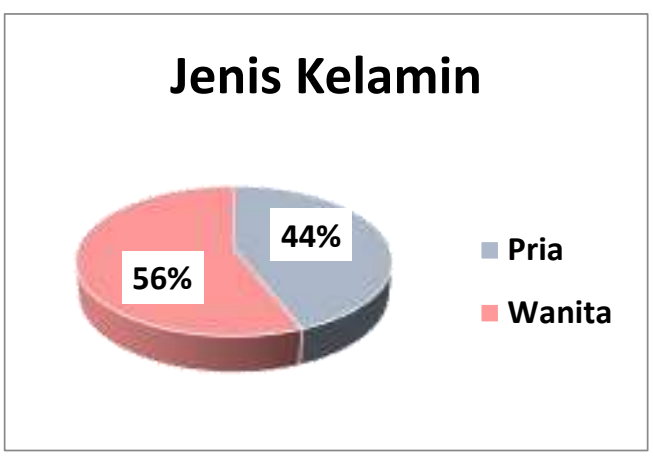

Sumber: Hasil Olahan Data Penulis (2020)

Gambar 1. Presentase Jenis Kelamin Responden

Telah diketahui berdasarkan Grafik 1. bahwa mayoritas jenis kelamin responden pengikut @kfcindonesia adalah wanita yaitu sebanyak 56 responden atau $56 \%$.

\section{Usia}

Responden pada penelitian ini berusia " $<17$ tahun" sebesar 3\%, "18-28 tahun" sebesar 77\%, "2939 tahun" sebesar $16 \%$ dan " $>40$ " tahun sebesar $4 \%$. Karakteristik usia responden akan dijelaskan pada grafik sebagai berikut:

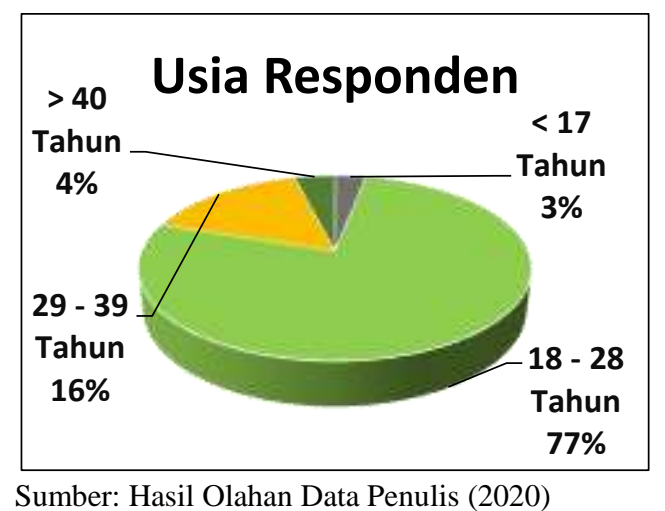

Gambar 2. Presentase Usia Responden

Responden dengan rentang usia 18-28 tahun mendominasi sebesar $77 \%$. Fielding K, Head B (2012) dalam Ulfa (2017) menyatakan bahwa, perilaku mengenai ramah lingkungan banyak didukung oleh masyarakat pada usia 12-24 tahun, mereka merasa bahwa masyarakat sekitar perlu bertanggung jawab dalam menjaga lingkungannya.

\section{Pendidikan}

Penulis membagi karakteristik pendidikan responden menjadi enam kategori dengan jumlah presentase yang didapat diantaranya, pendidikan sekolah dasar sebesar 0\%, SMP sebesar 4\%, SMA sebesar 56\%, D3 sebesar 8\%, S1 sebesar 32\%, S2/S3 sebesar $0 \%$. Karakteristik jenjang pendidikan responden akan dijelaskan pada grafik di bawah ini:

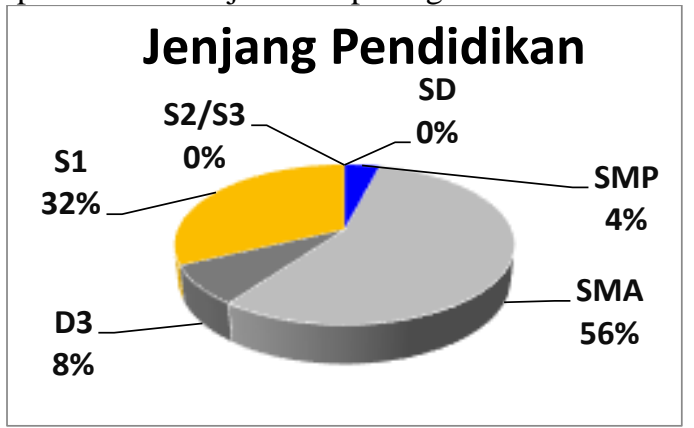

Sumber: Hasil Olahan Data Penulis (2020)

Gambar 3. Presentase Jenjang Pendidikan

Jenjang pendidikan responden dalam penelitian ini mayoritas adalah lulusan SMA yaitu sebesar 56\% dan lulusan S1 sebesar 32\%. Nielsen, sebuah lembaga riset yang bergerak dibidang informasi global serta media mengungkapkan bahwa, gerenasi $\mathrm{Z}$ atau anak-anak remaja tersebut terlahir pada era digital penggunaan akses internet, dan 
teknologi telah menjadi sebuah kebutuhan mereka sehinga sudah tidak terasa asing lagi (Ulfa, 2017).

\section{Pekerjaan}

Terdapat 6 kategori pekerjaan diantaranya pelajar atau mahasiswa sebesar 52\%, karyawan swasta sebesar $22 \%$, PNS sebesar $2 \%$, wiraswasta $12 \%$, IRT sebesar 5\%, dan lainnya sebesar $7 \%$. Kategori lainnya yang dimaksud adalah responden yang memiliki pekerjaan diluar dari yang sudah disediakan. Jumlah karakteristik pekerjaan responden dapat dilihat pada grafik berikut:

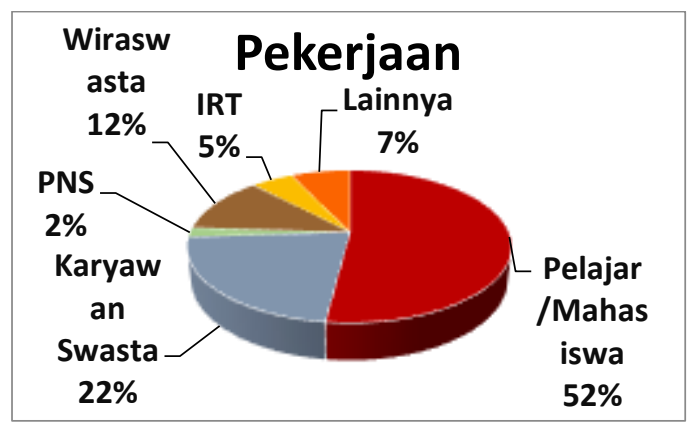

Sumber: Hasil Olahan Data Penulis (2020)

Gambar 4. Presentase Pekerjaan Responden

\section{Pendapatan}

Karakteristik pendapatan res-ponden dibagi menjadi lima yaitu < Rp 500.000 (A) sebesar 39\%, Rp 500.000-Rp 2.000.000 (B) sebesar 23\% Rp 2.000.000-Rp 3.500.000 (C) sebesar 8\%, Rp 3.500.000-Rp 5.000.000 (D) sebesar 16\%, > Rp 5.000.000 (E) sebesar 14\%. Karakteristik pendapatan responden akan dijelaskan pada grafik sebagai berikut:

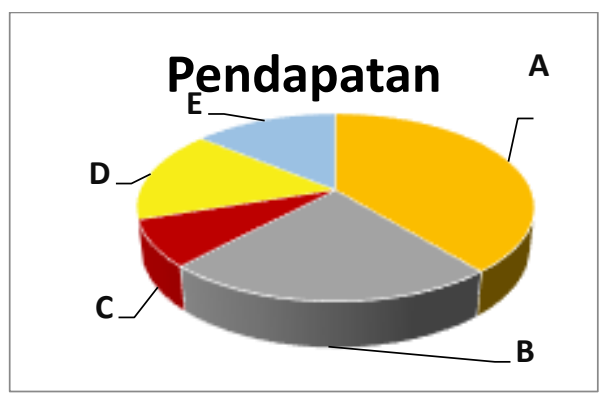

Sumber: Hasil Olahan Data Penulis (2020)

Gambar 5. Presentase Pendapatan Perbulan

Pendapatan responden paling banyak berada di $<500.000$ sebanyak 39\%. Presentase ini sejalan dengan kategori pekerjaan yaitu banyaknya responden yang berprofesi sebagai pelajar atau mahasiswa. Hal ini dikarenakan mahasiswa belum bekerja dan hanya mendapatkan pemasukan dari orang tua.

\section{Wilayah}

Dibagi menjadi lima wilayah tempat tinggal yaitu, Jabodetabek sebesar 38\%, Jawa Barat sebesar 14\%, Jawa Tengah sebesar 15\%, Jawa Timur sebesar $13 \%$ dan Luar Pulau Jawa sebesar $20 \%$.

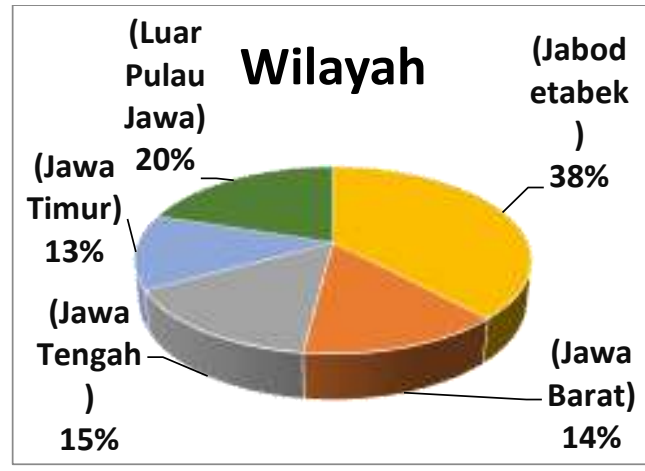

Sumber: Hasil Olahan Data Penulis (2020)

Gambar 6. Presentase Tempat Tinggal

Berdasarkan grafik di atas, wilayah responden mayoritas berada di wilayah Jabodetabek yakni sebesar $38 \%$. Data ini sejalan dengan penelitian yang telah dilakukan oleh lembaga penelitian Australia yaitu Roy Morgan yang menunjukkan bahwa lebih dari 12 juta masyarakat wilayah Jakarta, Bogor, Depok, Tanggerang (Jabodetabek) lebih berminat makan di restoran cepat saji. Serta sekitar $40,2 \%$ atau hampir 8,5 juta penduduk di Jabodetabek sangat berminat makan di KFC (www.tribuntravel.com, 16/9/2018).

Hasil Tanggapan Responden Mengenai Program Kampanye Budaya Beberes (X)

Pada sub-bab ini akan dijelaskan seberapa besar presentase pada variabel program kampanye budaya beberes, dilihat dari hasil kuesioner yang telah ditanggapi oleh 100 responden.

\section{Pesan}

Dalam penelitian ini pesan yang disampaikan oleh @kfcindonesia mudah dipahami atau tidak. Hasil tanggapan responden mengenai pesan dapat dijelaskan dengan grafik di bawah ini:

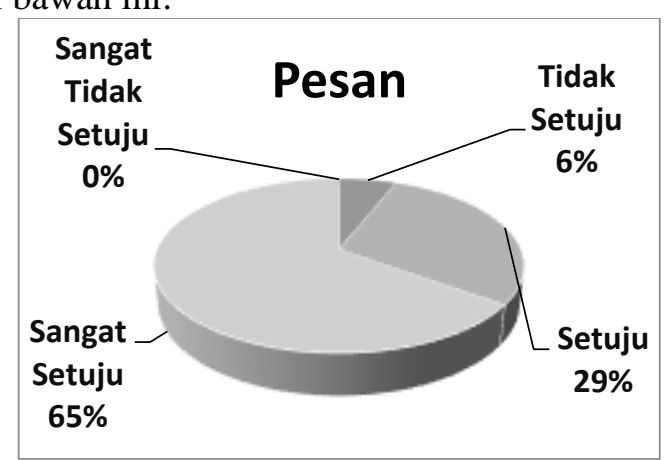

Sumber: Hasil Olahan Data Penulis (2020)

Gambar 7. Presentase Indikator Pesan

Responden yang menyatakan "sangat setuju" sebesar $65 \%$, "setuju" sebesar $29 \%$, "tidak setuju" 
sebesar 6\% dan "sangat tidak setuju" sebesar 0\%. Hal ini menunjukkan sebagian besar responden menyetujui bahwa pesan mengenai program kampanye budaya beberes mudah untuk dimengerti.

\section{Saluran}

Pengertian saluran dalam penelitian ini adalah saluran yang digunakan untuk menjalankan pogram kampanye budaya beberes yakni melalui media sosial instagram. Hasil tanggapan responden dapat dijelaskan berdasarkan grafik seperti di bawah ini:

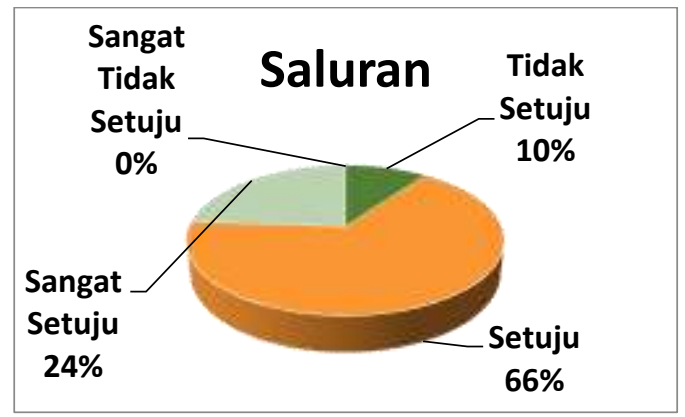

Sumber: Hasil Olahan Data Penulis (2020)

Gambar 8. Presentase Indikator Saluran

Responden yang menyatakan "sangat setuju" sebesar 24\%, "setuju" sebesar 66\%, "tidak setuju" $10 \%$, dan "sangat tidak setuju" sebesar $0 \%$. Sebagian besar responden menyatakan "setuju" yakni sebanyak $66 \%$. Hal ini menunjukkan bahwa saluran yang digunakan untuk melakukan kampanye budaya beberes sudah cukup tepat serta admin cukup cepat dalam menanggapi komentar dan me-repost instastory konsumen yang melakukan budaya beberes.

\section{Hasil Tanggapan Responden Mengenai Partisipasi Masyarakat (Y)}

Pada sub-bab ini akan dijelaskan seberapa besar presentase pada variabel Partisipasi Masyarakat berdasarkan hasil kuesioner yang telah ditanggapi oleh 100 responden.

\section{Memberikan Informasi}

Dalam penelitian ini "memberikan informasi" yang dimaksud adalah akun @kfcindonesia dapat memberikan informasi yang dapat dipahami, dimengerti, dan tertanam di dalam benak pengikutnya, mengenai informasi budaya beberes.

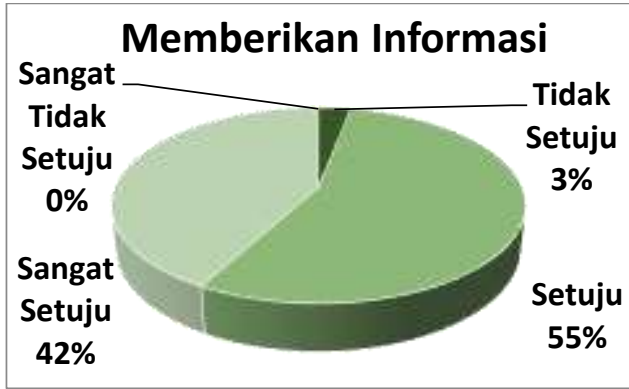

Gambar 8. Presentase Indikator Memberikan Informasi (Sumber: Data diolah Penulis, 2020)

Responden yang menyatakan "sangat setuju" sebesar 42\%, "setuju" sebesar 55\%, "tidak setuju" 3\%, "sangat tidak setuju setuju" sebesar $0 \%$.

\section{Konsultasi}

Di dalam indikator penelitian ini, "konsultasi" meliputi komentar yang berisi sebuah pendapat yang diberikan oleh pengikut. Dapat dilihat pada presentase hasil sebagai berikut:

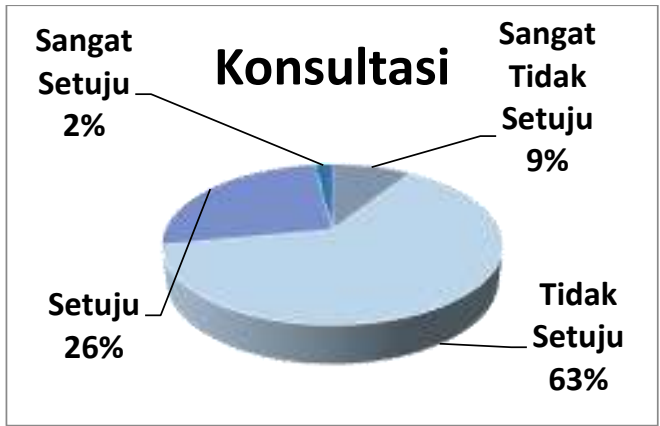

Sumber: Hasil Olahan Data Penulis (2020)

Gambar 9. Presentase Indikator Konsultasi

Grafik 10. menunjukkan responden yang menyatakan "sangat setuju" sebesar $2 \%$, "setuju" sebesar 26\%, "tidak setuju" sebesar $63 \%$ dan sangat tidak setuju sebesar $9 \%$. Hal ini menyatakan bahwa sebesar $63 \%$ responden yang memilih tidak setuju lebih dominan.

\section{Pengambilan Keputusan}

Dalam penelitian ini indikator "pengambilan keputusan" yaitu ikut menyebarkan informasi budaya beberes kepada orang sekitarnya, mengunggah ulang unggahan kampanye budaya beberes di akun pribadi, dan menyebar kan ke media sosial selain instagram. Grafik presentase pengambilan keputusan dapat dilihat di bawah ini: 


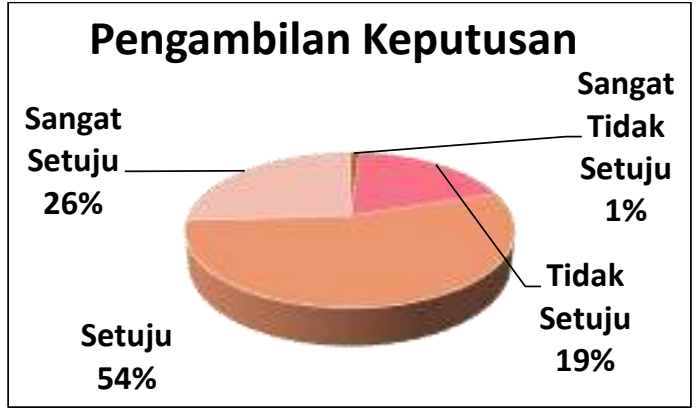

Sumber: Hasil Olahan Data Penulis (2020)

Gambar 10. Presentase Indikator Pengambilan Keputusan

Grafik di atas menunjukkan responden yang menyatakan "sangat setuju" sebesar $26 \%$, "setuju" sebesar 54\%, "tidak setuju" sebesar $19 \%$ dan sangat tidak setuju sebesar $1 \%$. Hal ini menunjukkan bahwa responden yang memilih "setuju" mendominasi yakni sebesar 54\%.

\section{Bertindak Bersama}

Dalam penelitian ini bertindak bersama adalah ikut melakukan budaya beberes, mengunggah foto atau video saat melakukan budaya beberes di akun pribadi, serta menjadikan budaya beberes sebagai kebiasaan ketika makan di restoran lain.

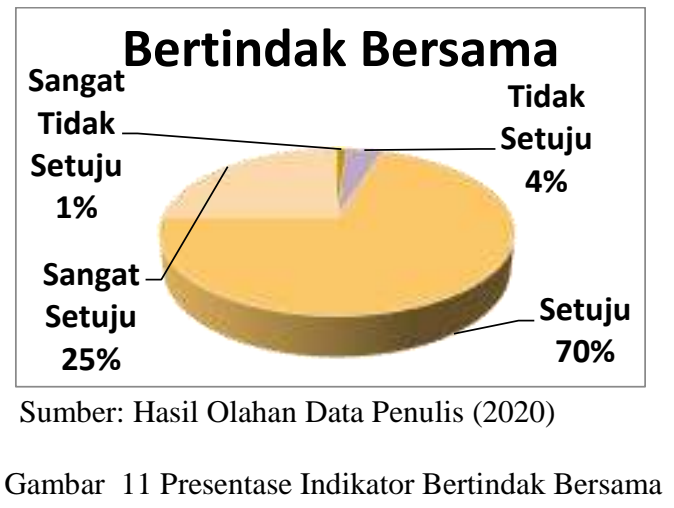

Responden yang menyatakan "sangat setuju" sebesar $25 \%$, "setuju" sebesar $70 \%$, "tidak setuju" sebesar 4\%, dan "sangat tidak setuju" sebesar $1 \%$. Responden yang memilih "setuju" mendominasi yakni sebesar 70\%.

\section{Memberikan Dukungan}

Dalam penelitian ini bentuk memberikan dukungan adalah melalui pengguanaan fitur tag, tagar, menyukai unggahan budaya beberes, dan memberikan saran kepada @ kfcindonesia terkait kampanye tersebut. Presentase memberikan dukungan akan dijelaskan dengan grafik di bawah ini:

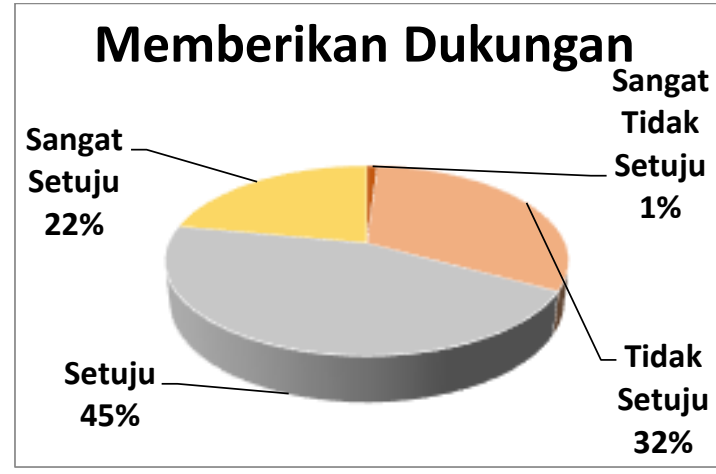

Sumber: Hasil Olahan Data Penulis (2020)

Gambar 12. Presentase Indikator Pengambilan Keputusan

Responden yang memilih "sangat setuju" sebesar 22\%, "setuju" sebesar 45\%, "tidak setuju" sebesar $32 \%$ dan "sangat tidak setuju" sebesar 1\%. Berdasarkan Grafik 13. responden yang memilih setuju lebih dominan yaitu sebesar $45 \%$.

\section{Pengujian Koefisien Determinasi $\left(\mathbf{R}^{2}\right)$}

Koefisien determinasi merupakan salah satu bagian dari regresi linier sederhana, yang digunakan untuk mengukur kemampuan variabel independen (X) dalam menjelaskan variabel dependen $(\mathrm{Y})$, nilai koefisien determinasi dapat dilihat melalui tabel berikut:

Tabel 1. Koefisien Determinasi Program Kampanye Budaya Beberes dengan Partisipasi Masyarakat

\begin{tabular}{|c|c|c|}
\hline \multicolumn{3}{|c|}{ Model Summary } \\
\hline & $R$ & $R$ Square \\
\hline 1 &, $679 \mathrm{a}$ & \\
\hline a. Predictors: (Constant), \\
Kampanye Budaya Beberes \\
\hline
\end{tabular}

Berdasarkan hasil Tabel 1. ditampilkan bahwa nilai koefisien korelasi $(\mathrm{R})=0,679$ dan nilai koefisien determinasi ( R Square $)=0,461$. Telah diketahui nilai koefisien determinasi (R Square) sebesar 46,1\% $(0,461 \times 100 \%)$. Hal ini menunjukkan pengertian bahwa sebesar $46,1 \%$ dari partisipasi masyarakat untuk membuang sampah sendiri ditentukan oleh kampanye budaya beberes yang dilakukan oleh @ kfcindonesia. Dengan kata lain, program kampanye budaya beberes memberikan kontribusi sebesar $46,1 \%$ terhadap variabel partisipasi masyarakat. Sedangkan sisanya yakni sebesar 53,9\% (100\%$46,1 \%=53,9 \%$ ) variabel partisipasi masyarakat dijelaskan oleh faktor lainnya yang tidak diteliti dalam penelitian ini. Faktor-faktor partisipasi 
masyarakat yang lainnya yaitu: Interest dari partisipan, hadiah dari suatu kegiatan, adanya keuntungan dari kegiatan, dan motivasi luar.

\section{Uji Signifikansi (Uji t)}

Uji t dapat mengetahui apakah model regresi dalam penelitian ini merupakan model regresi yang signifikan atau tidak. Syarat model regresi yang signifikan adalah jika t-hitung $>\mathrm{t}$ tabel dan nilai signifikansi (sig.) $<0,05$. Jika terbukti signifikan, maka model regresi dapat digunakan untuk memprediksi variabel dependen (Y). Dalam uji signifikansi (uji t) penulis menggunakan bantuan program SPSS versi 22 for windows, dapat dilihat pada tabel sebagai berikut:

Tabel 2. Uji Signifikansi (Uji t) Pengaruh Program Kampanye Budaya Beberes Terhadap Partisipasi

\begin{tabular}{|l|l|l|l|}
\hline \multicolumn{1}{|c|}{ Model } & $\begin{array}{c}\text { Nilai t- } \\
\text { hitung }\end{array}$ & $\begin{array}{c}\text { Nilai t- } \\
\text { tabel }\end{array}$ & Sig. \\
\hline (Constant) $(\alpha)$ & 2,802 & $\begin{array}{c}1,98 \\
4\end{array}$ &, 006 \\
\hline $\begin{array}{l}\text { Kampanye } \\
\text { Budaya Beberes } \\
(\beta)\end{array}$ & 9,148 & $\begin{array}{c}1,98 \\
4\end{array}$ &, 000 \\
\hline \multicolumn{4}{|l|}{$\begin{array}{l}\text { a. Dependent Variable: Partisipasi } \\
\text { Masyarakat (Y) }\end{array}$} \\
\hline
\end{tabular}

Sumber: Hasil Olahan Data SPSS Penulis (2020)

Hasil pengujian selanjutnya yakni signifikansi pada model Kampanye Budaya Beberes, diperoleh nilai t-hitung sebesar 9,148 dengan nilai t-tabel sebesar 1,984 yang menunjukkan bahwa t-hitung lebih besar dari pada t-tabel. Maka program kampaye budaya beberes berpengaruh terhadap partisipasi masyarakat dengan nilai signifikansi sebesar 0,000 lebih kecil dari standar yang dipersyaratkan $(\alpha<$ $0,05)$, maka hipotesis Ho ditolak dan Ha diterima.

\section{Persamaan Regresi Linier Sederhana}

Penjelasan data hasil analisis regresi linier sederhana dengan bantuan SPSS 22,0 for windows. Dapat dilihat pada tabel di bawah ini:

Tabel 3. Analisis Regresi Linier Sederhana

\begin{tabular}{|c|c|c|c|c|c|}
\hline & \multicolumn{5}{|c|}{ Coefficients $\mathbf{a}$} \\
\hline & \multirow[t]{2}{*}{ Model } & $\begin{array}{r}\text { Unstano } \\
\text { Coeffi }\end{array}$ & $\begin{array}{l}\text { rdized } \\
\text { ents }\end{array}$ & \multirow{2}{*}{$t$} & \multirow{2}{*}{ Sig } \\
\hline & & $B$ & $\begin{array}{c}\text { Std. } \\
\text { Error }\end{array}$ & & \\
\hline 1 & $\begin{array}{l}\text { (Constant) } \\
(\alpha)\end{array}$ & 13,596 & 4,853 & 2,802 & ,006 \\
\hline
\end{tabular}

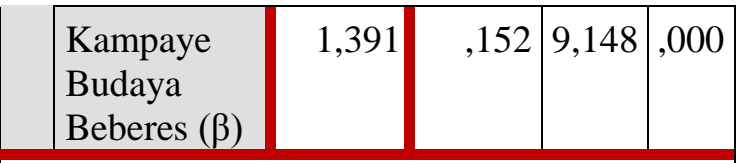

a. Dependent Variable: Partisipasi Masyarakat Sumber: Hasil Olahan Data SPSS Penulis (2020)

Pada kolom Unstandardized Coefficients B merupakan angka-angka koefisien regresi yang menunjukkan hubungan fungsional antara variavel independen $(\mathrm{X})$ dan dependen $(\mathrm{Y})$ dengan koefisien konstanta $(\alpha)$ sebesar 13,596 dan koefisien kampanye budaya beberes $(\beta)$ sebesar 1,391 sehingga diperoleh persamaan regresi sebagai berikut:

$$
\begin{gathered}
\mathrm{Y}=\alpha+\beta X \\
\mathrm{Y}=\mathbf{1 3 , 5 9 6}+\mathbf{1 , 3 9 1 X}
\end{gathered}
$$

\section{Keterangan:}

$\alpha=$ Nilai koefisien konstan

$\beta=$ Nilai koefisien regresi variabel program kampanye budaya beberes

$\mathrm{Y}=$ Partisipasi Masyarakat

$\mathrm{X}=$ Program Kampanye Budaya Beberes

Koefisien kampanye budaya beberes $(\beta)=$ 1,391 bernialai positif. Koefisien konstanta $(\alpha)=$ 13,596 bernilai positif, artinya jika nilai independen adalah 0 maka nilai variabel dependen tetap sebesar 13,596. Setiap program kampanye budaya beberes meningkat sebesar $1 \%$ maka partisipasi masyarakat akan meningkat sebesar 1,391, serta sebaliknya apabila program kampanye budaya beberes turun $1 \%$ maka partisipasi masyarakat akan menurun sebesar 1,391 .

\section{KESIMPULAN}

Berdasarkan hasil penelitian mengenai program kampanye budaya beberes terhadap partisipasi masyarakat untuk membuang sampah sendiri, dapat disimpulkan bahwa terdapat pengaruh positif dan signifikan antara program kampanye budaya beberes yang dilakukan oleh KFC Indonesia terhadap partisipasi masyarakat (Ha diterima). Kampanye budaya beberes berpengaruh sebesar $46,1 \%$.

Partisipasi Masyarakat juga tergolong pada taraf yang baik. Pada indikator Memberikan Informasi jumlah keseluruhan yang memilih kategori "sangat setuju" dan "setuju" sebanyak 97\% dan pada indikator Bertindak Bersama merupakan tingkatan partisipasi yang keempat keseluruhan yang memilih kategori "sangat setuju" dan "setuju" sebanyak 95\%. Hal tersebut menjelaskan bahwa partisipasi masyarakat cenderung mau menerima dan memahami informasi kampanye budaya beberes, serta mau malakukan kampanye budaya beberes dan menjadikannya budaya beberes sebuah kebiasaan (habbit). 


\section{REFERENSI}

Anggaini, Hardiana Calisca. (2014). Pengaruh Program Kampanye Say No To Plastic Bag Oleh The Body Shop Terhadap Partisipasi Masyarakat. Jurnal Wacana, XII, No.02. Juni 2014.

Bernays. (1952). Public Relation. Jakarta: Panitia Penerbit.

Djalal, Fasli dan Dedi Supriadi. (2001). Reformasi Pendidikan Dalam Konteks Otonomi Daerah. Yogyakarta: Adicita Karya Nusa.

Mardikanto,Totok. (2010). Komunikasi pembangunan. Surakarta: UNS Press.

Ruslan, Rosady. (2019). Kiat Dan Strategi Kampanye Public Relations. Jakarta: Raja Grafindo Persada.

Ulfa, Shabrina Ghina. (2017). Earth Hour Bogor Sebagai Media Kampanye Kampanye Lingkungan. (Skripsi, Institut Pertanian Bogor, 2017). Diakses dari http://repository.ipb.ac.id/jspui/bitstream/1234 56789/88528/1/I17gsu.pdf.

Venus, Antar. (2019) Manajemen Kampanye Edisi Revisi. Bandung: Simbiosa Rekatama Media.

\section{PROFIL PENULIS}

Siti Khadijah merupakan dosen Fakultas Komunikasi Sastra dan Bahasa, Universitas Islam “45” Bekasi.

Siti Marfuah Yuliati merupakan mahasiswa Program Studi Ilmu Komunikasi Fakultas Komunikasi Sastra dan Bahasa, Universitas Islam “45” Bekasi 